\title{
INDENTIFIKASI DAYA TARIK PARIWISATA PERKOTAAN TERHADAP TINGKAT KUNJUNGAN WISATAWAN DI KOTA MATARAM LOMBOK
}

Yustisia Pasfatima Mbulu ${ }^{1}$

Universitas Pancasila

Yustisia.pm@univpancasila.ac.id

\author{
Riza Firmansyah ${ }^{2}$ \\ Universitas Pancasila \\ rfirmansyah13@gmail.com \\ Nungky Puspita ${ }^{3}$ \\ Universitas Pancasila \\ nungky.puspita@univpancasila.ac.id
}

\begin{abstract}
ABSTRAK
Penelitian ini bertujuan untuk mengidentifikasikan elemen pokok pariwisata perkotaan sebagai daya tarik wisata kota di Mataram Lombok dan mengidentifikasikan pengembangan pariwisata perkotaan terhadap tingkat kunjungan wisatawan di Mataram Lombok. Pengumpulan data melalui survei atau observasi lapangan, wawancara, dan melakukan FGD dengan Dinas Pariwisata kota Mataram Lombok, ASITA, PHRI, Pengelola Destinasi, dan Tokoh Masyarakat. Serta menggunakan metode analisis SWOT (Strength, Weakness, Oppurtunity dan Treath analysis). Hasil penelitian ini menyatakan bahwa elemen pokok pariwisata perkotaan yang terdiri dari Kota Bersejarah (Historic District), Kawasan Pinggiran Pantai (Waterfronts), Pusat Konvensi dan Pameran (Convention Center and Exhibitions), Festival dan Acara (Festivals \& Events), Daerah Wisata Perkotaan (Special Visitor District), Warga \& Karyawan yang mendukung pariwisata (Tourism Employees and Residents as City Advocates), Fasilitas Ritel dan Katering (Retail and Catering Facilities) hanya ada satu elemen yang tidak di penuhi oleh kota Mataram Lombok sebagai daya tarik wisata kota yaitu unsur Pusat Konvensi dan Pameran (Convention Center and Exhibitions). Sedangkan pengembangan pariwisata perkotaan dalam meningkatkan kunjungan wisatawan dengan cara kerjasama dengan pihak travel untuk merancang paket wisata khusus kota mataram, pihak swasta untuk menambah armada angkutan massal, membentuk pusat informasi khusus pariwisata perkotaan, membuat fasilitas bagi wisatawan yang lanjut usia dan berkebutuhan khusus, bekerjasama dengan pemerintah pusat dan pemerintah daerah untuk membangun gedung pusat konvensi, koordinasi antar SKPD untuk membuat petunjuk arah dalam dua bahasa, bekerjasama dengan instansi terkait dalam pembangunan saluran air bersih, Koordinasi dengan pemerintah daerah, pemerintah pusat dan pihak airlines untuk penambahan rute penerbangan internasional, Bekerjasama dengan pemerintah daerah, pemerintah pusat dan pihak swasta untuk mempromosikan agenda festival yang ada dikota Mataram Lombok.
\end{abstract}

Kata Kunci: Elemen Pokok Pariwisata Perkotaan, Pariwisata Perkotaan dan SWOT 


\title{
IDENTIFICATION OF URBAN TOURISM ATTRACTION TOWARDS THE LEVEL OF TOURIST VISIT IN MATARAM LOMBOK
}

\begin{abstract}
This research aims to identify the main elements of urban tourism as a tourist attraction in the city of Lombok Mataram and identify the development of urban tourism to the level of tourist arrivals in Lombok Mataram.This research used qualitative descriptive method from collecting data through survey or field observation, interview, and conducting FGD with Tourism Office of Mataram Lombok, ASITA, PHRI, Destination Manager, and Community Leader. And use SWOT analysis method (Strength, Weakness, Opportunity and Threat analysis). The results of this research have been identified seven elements of urban tourism consisting of the Historic District, Waterfronts, Convention Centers and Exhibitions, festivals and Events, the Special Visitor District, the Tourism Employees and Residents as City Advocates, the Retail and Catering Facilities there is only one element not covered by The city of Mataram Lombok as a tourist attraction of the city that is the element of Convention Center and Exhibition. Meanwhile, to analyze the development of urban tourism in increasing tourist visit can be seen from SWOT analysis by using WO strategy which include cooperation with travel party to design special tour package of mataram city, in cooperation with private party to add mass transportation fleet, establishing special urban tourism information center in Mataram Lombok, making facilities for the elderly and special needs traveler, in cooperation with the central government and local governments to build convention center building, coordination between SKPD to create bilingual directions, in cooperation with related institutions in the construction of water supply, Coordination with Local government, central government and airlines for the addition of international flight routes, Cooperate with local government, central government and private parties to promote the festival agenda in the city of Lombok Mataram.
\end{abstract}

Keywords: Main Elements of Urban Tourism, Urban Tourism Development and SWOT

\section{PENDAHULUAN}

Pariwisata merupakan sektor unggulan bagi Indonesia. Meningkatnya destinasi dan investasi pariwisata menjadikan pariwisata sebagai faktor kunci dalam pendapatan ekspor, penciptaan lapangan kerja, pengembangan usaha dan infrastruktur. Pariwisata telah mengalami ekspansi dan diversifikasi berkelanjutan, dan menjadi salah satu sektor ekonomi yang terbesar dan tercepat pertumbuhannya di dunia. Meskipun krisis global terjadi beberapa kali, jumlah perjalanan wisatawan internasional tetap menunjukkan pertumbuhan yang positif 25 juta orang tahun 1950, 278 juta orang tahun 1980, 528 juta orang tahun 1995, 1,1 milyar orang tahun 2014 (Ratman. 2016). 
Menurut Passenger Exit Survery (2014) dalam Ratman (2016) Portofolio produk pariwisata terdiri dari alam (35\%), budaya (60\%) dan buatan Manusia (5\%). Portofolio Produk bidang budaya mempunyai unsur-unsur yaitu warisan budaya dan sejarah (20\%), wisata belanja dan kuliner (45\%), serta wisata kota dan desa (35\%). Dilihat dari unsur-unsur bidang budaya bahwa wisata kota dan desa mendapatkan bagian $35 \%$ maka pengembangan wisata kota dan desa mempunyai peran yang besar dalam kemajuan pariwisata di Indonesia.

Sektor pariwisata perkotaan bisa dijadikan salah satu industri pokok yang menopang perekonomian kota, jika direncanakan, dikembangkan dan dikelola dengan baik, pariwisata perkotaan bukan saja mengucurkan devisa yang lumayan besar, tetapi juga menjadi katalis bagi pembangunan kota secara berkelanjutan (Subinarto.D. 2016).

Menurut Law (1996:1) dalam Adriani Yani (2011) kota merupakan jenis destinasi pariwisata yang paling penting di dunia sejak tahun 1980-an. Sebagai fenomena kepariwisataan dunia, kota dipandang sebagai suatu proses kompleks yang terkait dengan budaya, gaya hidup, dan sekumpulan permintaan yang berbeda terhadap liburan dan perjalanan (Page, 1995: 1). Kota merupakan destinasi dengan multimotivasi, tidak seperti resor-resor pada umumnya (Law, 1996: 3). Orang yang pergi ke suatu kota untuk berbisnis, menyempatkan diri untuk mengunjungi museum atau galeri seni di kota yang dikunjunginya. Atau mereka yang dari luar negeri (wisatawan mancanegara) mengunjungi dan berwisata di kota tertentu sebagai pintu gerbang untuk mengunjungi daerah lain di sekitarnya (Law, 1996:3).

Pariwisata perkotaan memiliki karakteristik lain yang khas, berbeda dengan pariwisata pada umumnya yang daya tarik wisatawanya memang ditujukan hanya untuk mereka yang berwisata. Wisatawan perkotaan menggunakan fasilitas perkotaan yang juga digunakan oleh penduduk kota sebagai daya tarik wisatanya (Law, 1996: 4 dalam Andriani Yani 2011).

Menurut Ruetsche.J. (2006) Dalam bukunya Urban Tourism: Ekonomi Pengunjung dan Pertumbuhan Kota Besar, Law meneliti hubungan antara pariwisata dan daerah perkotaan. Dia membedakan antara elemen primer, sekunder, dan tambahan dari sumber daya pariwisata kota. Unsur utama memberikan alasan mengapa wisatawan mengunjungi kota. Unsur-unsur sekunder seperti akomodasi dan belanja serta elemen tambahan seperti transportasi atau informasi wisatawan juga sangat penting bagi keberhasilan pariwisata kota, namun bukan penarik utama pengunjung.

Salah satu kota yang mempunyai potensi dalam pengembangan pariwisata perkotaan adalah kota Mataram Lombok. Kota Mataram adalah Ibu kota Provinsi Nusa Tenggara Barat. Kota Mataram terdiri dari 6 kecamatan Ampenan, Cakranegara, Mataram, Pejanggik, Selaparang, dan Sekarbela dengan 50 kelurahan dan 297 lingkungan. Kota Mataram terletak pada $08^{\circ} 33^{\prime}-08^{\circ} 38^{\prime}$ LS dan $116^{\circ} 04^{\prime}-116^{\circ}$ $10^{\prime}$ BT. Selain ibukota propinsi, mataram juga telah menjadi pusat pemerintahan, pendidikan, perdagangan, industri dan jasa, serta saat ini sedang dikembangkan untuk menjadi kota pariwisata. Secara geografis wilayah kota Mataram mempunyai luas wilayah $61.30 \mathrm{~km} 2$ dengan batas-batas kabupaten Lombok Barat di bagian utara, timur dan selatan serta selat Lombok dibagian barat (www.mataram.bpk.go.id). 
Tabel 1.1

Data Kunjungan Wisatawan Ke Provinsi Nusa Tenggara Barat

\begin{tabular}{|l|l|l|l|l|l|}
\hline \multirow{2}{*}{$\begin{array}{l}\text { Jenis } \\
\text { Wisatawan }\end{array}$} & \multicolumn{5}{|c|}{ Tahun } \\
\cline { 2 - 6 } & $\mathbf{2 0 0 9}$ & $\mathbf{2 0 1 0}$ & $\mathbf{2 0 1 1}$ & $\mathbf{2 0 1 2}$ & $\mathbf{2 0 1 3}$ \\
\hline $\begin{array}{l}\text { Wisatawan } \\
\text { Mancanegara }\end{array}$ & 232.525 & 282.161 & 364.196 & 471.706 & 565.944 \\
\hline $\begin{array}{l}\text { Wisatawan } \\
\text { Nusantara }\end{array}$ & 386.845 & 443.227 & 522.684 & 691.436 & 791.658 \\
\hline
\end{tabular}

Sumber: Dinas Kebudayaan dan Pariwisata Provinsi 2009 - 2013

Dari data kunjungan wisatawan pada table 1.1 menyatakan bahwa setiap tahunnya baik wisatawan mancanegara maupun wisatawan nusantara jumlah kunjungan terus meningkat. Maka peluang untuk mengembangkan kota Mataram Lombok sebagai pariwisata perkotaan sangat besar. Potensi wisata perkotaan di Mataram Lombok untuk dikembangkan sebagai daya tarik wisata kota dilihat dari peninggalan-peninggalan sejarah, kota tua ampenan, daya tarik wisata alam, kerajinan Emas dan Mutiara serta agenda festival \& event. Maka perlu pengembangan pariwisata perkotaan yang baik untuk meningkatkan kunjungan wisatawan ke Mataram Lombok. Dengan demikian Penelitian ini bertujuan untuk mengidentifikasikan elemen pokok pariwisata perkotaan sebagai daya tarik wisata kota di Mataram Lombok dan mengidentifikasikan pengembangan pariwisata perkotaan terhadap tingkat kunjungan wisatawan di Mataram Lombok (lihat Gambar 1.1 Kerangka Pemikiran).

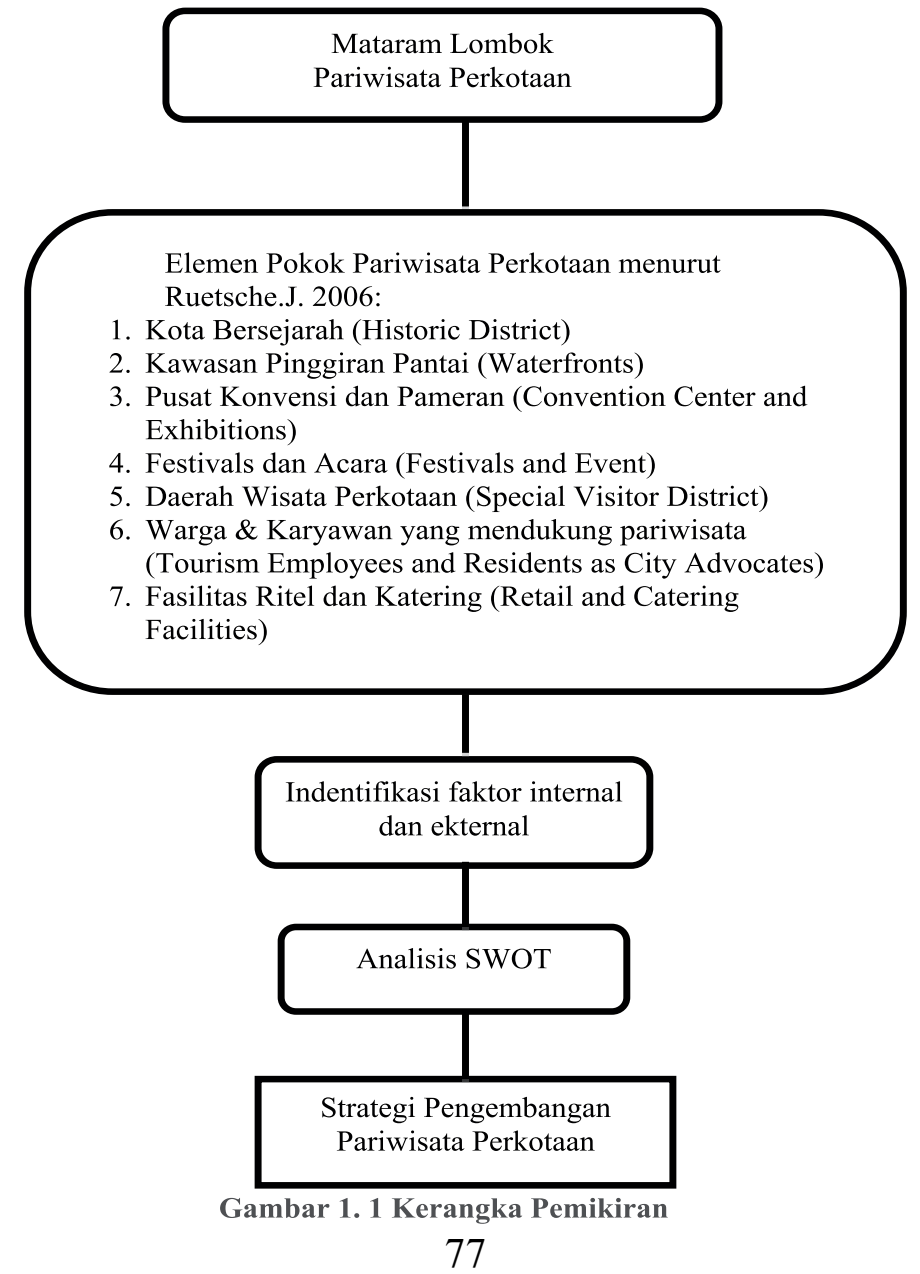




\section{METODOLOGI}

Penelitian ini menggunakan Metode kualitatif dengan pendekatan deskriptif. Metode kualitatif dengan pendekatan deskriptif adalah Penelitian kualitatif yang menghasilkan penemuan-penemuan yang tidak dapat dicapai dengan menggunakan prosedur stastistik atau dengan cara-cara kuantifikasi (Ghony \& Almanshur, 2012). Penelitian ini juga menggunakan Analisis SWOT (Strength, Weakness, Opportunities, Threat). Metode analisis SWOT untuk mengetahui faktor-faktor internal yaitu kekuatan, kelemahan yang dimiliki oleh pariwisata perkotaan di Mataram Lombok serta faktor eksternal yaitu peluang dan ancaman bagi pariwisata perkotaan di Mataram Lombok.

Data-data yang akan digunakan dalam penelitian ini dapat dikelompokkan menjadi dua jenis, yaitu:

1. Data primer, yang diperoleh melalui survei lapangan atau observasi, wawancara, FGD (Focus Group Discutions). FGD dilakukan dengan Dinas Pariwisata Kota Mataram Lombok, ASITA, PHRI, Pengelola Destinasi, dan Tokoh Masyarakat.

2. Data sekunder, yang diperoleh dari instansi-instansi terkait, dokumen studi yang pernah dilakukan pada pokok masalah yang sama serta menggali dari studi literatur. Data sekunder diperoleh dengan mengumpulkan bahan-bahan dari Dinas Pariwisatakota Mataram Lombok, mempelajari atau membaca buku-buku teks, serta dari website. Data sekunder dimaksudkan untuk melengkapi data primer sehingga diharapkan dapat menambah data yang tidak terdeteksi.

Tabel 1.2 Definisi Operasional Variable

\begin{tabular}{|c|c|c|}
\hline Variable & Indikator & Tekhnik Pengumpulan \\
\hline \multirow[t]{2}{*}{$\begin{array}{l}\text { Elemen pokok } \\
\text { pariwisata } \\
\text { perkotaan }\end{array}$} & $\begin{array}{ll}\text { - } & \text { Kota Bersejarah (Historic } \\
& \text { District) } \\
\text { - } & \text { Kawasan Pinggiran Pantai } \\
& \text { (Waterfronts) } \\
\text { - } & \text { Pusat Konvensi dan Pameran } \\
\text { (Convention Center and } \\
\text { Exhibitions) } \\
\text { - Festivals dan Acara (Festivals } \\
\text { and Event) } \\
\text { Daerah Wisata Perkotaan } \\
\text { (Special Visitor District) }\end{array}$ & $\begin{array}{l}\text { - Wawancara,Observasi, } \\
\text { - Wawancara,Observasi, } \\
\text { - Wawancara,Observasi, } \\
\text { - Wawancara,Observasi, }\end{array}$ \\
\hline & $\begin{array}{ll}\text { - } & \text { Warga \& Karyawan yang } \\
\text { mendukung pariwisata } \\
\text { (Tourism Employees and } \\
\text { Residents as City Advocates) } \\
\text { - Fasilitas Ritel dan Katering } \\
\text { (Retail and Catering Facilities) }\end{array}$ & \\
\hline $\begin{array}{l}\text { Analisis } \\
\text { SWOT }\end{array}$ & $\begin{array}{ll}\text { - } & \text { Kekuatan } \\
\text { - } & \text { Kelemahan } \\
\text { - } & \text { Peluang } \\
\text { - } & \text { Ancaman }\end{array}$ & $\begin{array}{l}\text { - Wawancara, Observasi } \\
\text { - Wawancara, Observasi } \\
\text { - Wawancara, Observasi } \\
\text { - Wawancara, Observasi }\end{array}$ \\
\hline
\end{tabular}




\section{HASIL DAN PEMBAHASAN}

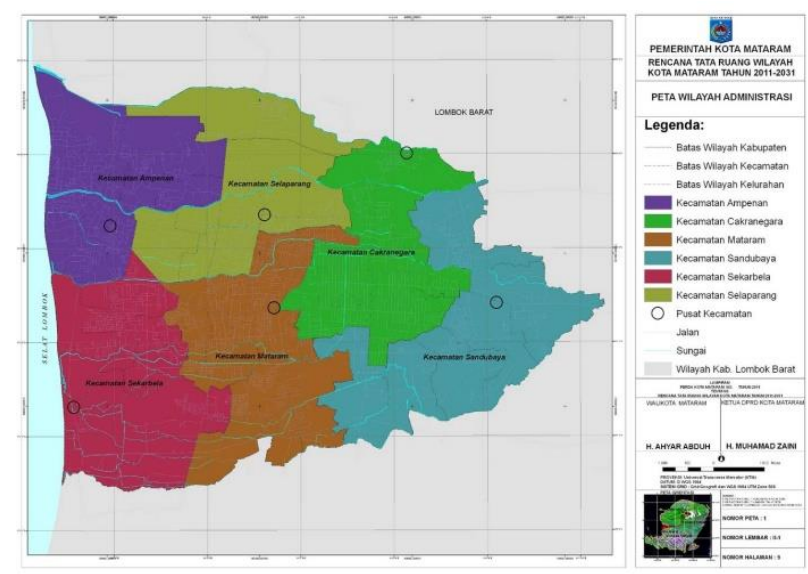

Gambar 1.4 Peta Kota Mataram Lombok Sumber: Peta-kota.blogspot.com

\section{a. Elemen Pokok Pariwisata Perkotaan Sebagai Daya Tarik Wisata Kota di Mataram Lombok.}

- Kota Bersejarah (Historic District)

Menurut Ruetsche.J.2006 Atribut kota bersejarah harus menekankan pada karakter lokal dari daerah tersebut. Kota bersejarah umumnya sangat ramah terhadap pejalan kaki dengan perpaduan antara atraksi dan fasilitas yang mudah dijangkau. Di luar komponen pendidikan pengunjung, pengunjung juga dapat merasakan pengalaman berkunjung yang mudah diingat. Dengan demikian, kota yang memiliki warisan sejarah sebagai titik jual utama dan dapat dikembangkan sebagai produk wisata kota yang dimiliki.

Salah satu peninggalan sejarah di kota Mataram Lombok adalah Taman Mayura terletak dekat komplek bisnis dan pertokoan di daerah Cakranegara, Mataram. Taman Maruya dibangun oleh Anak Agung Ngurah Karangsem pada tahun 1744, taman ini dibangun untuk peristirahatan Raja. Sebelum disebut Taman Mayura, taman ini bernama Taman kalepung yang artinya suara jatuhnya air dari telaga. Karena taman kalepung ini banyak dihuni oleh ular maka didatangkanlah burung merek untuk membasmi ular-ular tersebut. Sejak itulah taman itu disebut taman mayura, yang dalam bahasa sansekerta Mayura berarti Merak. Lokasi di taman Mayura memiliki Kolam besar dan ditengah-tengah kolam ada bangunan tempat peristirahat Raja (dispar.mataramkota.go.id). 

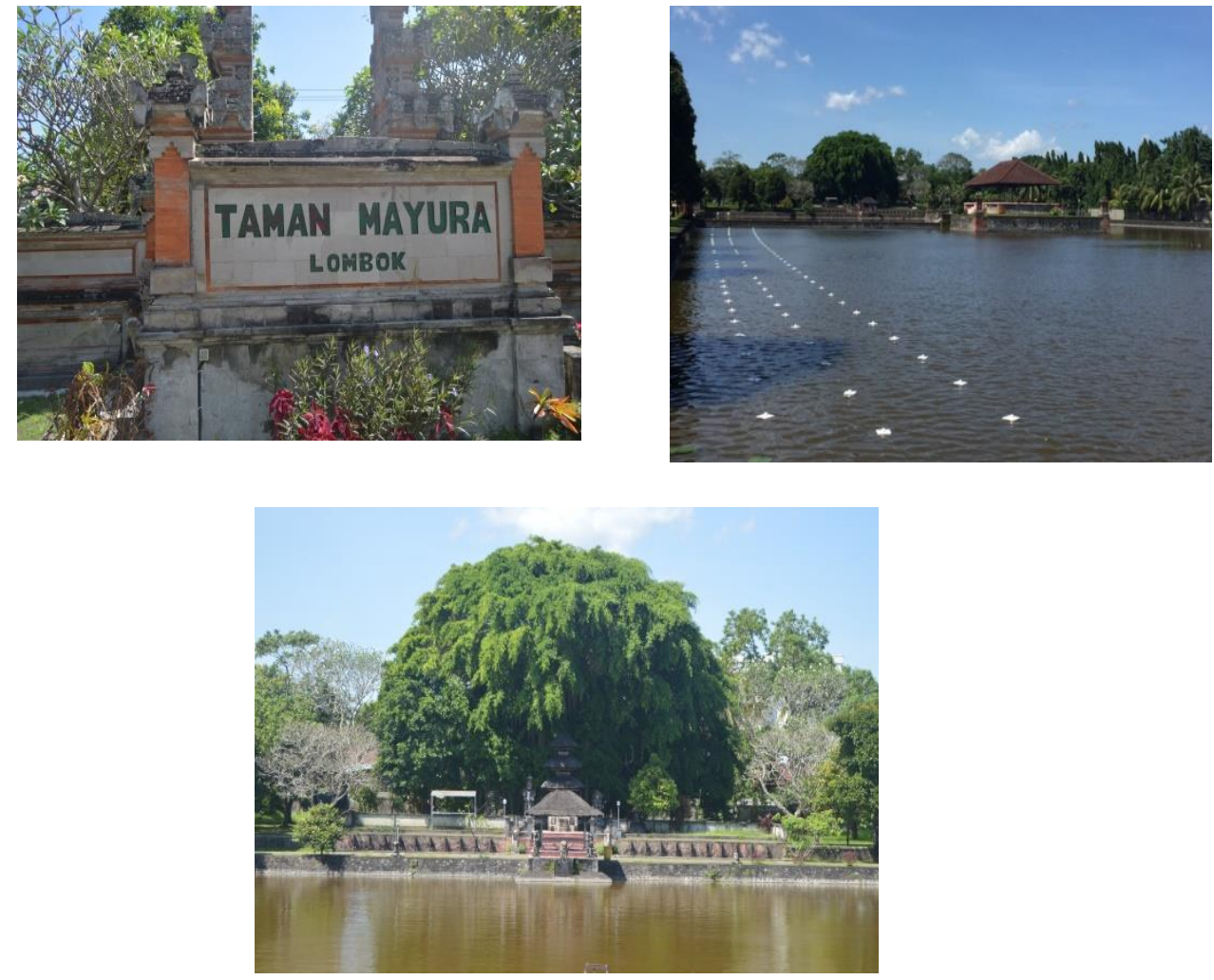

Gambar 1.5 Taman Mayura Lombok Sumber Foto: Dokumen Pribadi

Taman Mayura Lombok merupakan bagian dari unsur Kota Bersejarah (Historic District) dilihat dari bangunan sejarah yang memiliki karakter khas atau karakter lokal dari kota Mataram Lombok. Taman Mayura bisa memberikan pengalaman yang mengesankan pada wisatawan saat berkunjung karena dapat melihat langsung bangunan bersejarah yang terletak di tengah kota, serta merasakan suasana religi karena terdapat pura diarea taman mayura. Dengan demikian Taman Mayura mempunyai nilai lebih untuk dijadikan daya tarik wisata kota karena didukung oleh unsur-unsur bangunan bersejarah dan merupakan karakter khas dari kota Mataram Lombok.

- Kawasan Pinggiran Pantai (WaterFronts)

Menurut Ruetsche.J.2006 tidak masalah apakah itu untuk transportasi, industri, atau hiburan, Kawasan Pinggiran Pantai di perkotaan selalu menarik dari kebutuhan untuk bersenang-senang. Akhir-akhir ini, kota-kota dan investor swasta memperhatikan pantai karena kawasan pinggiran pantai memiliki berbagai peluang untuk pengembangan pariwisata, ekonomi, dan masyarakat.

Pantai Tanjung Karang yang secara administrasi berada di kelurahan Tanjung karang, kecamatan Ampenan, Kota Mataram dan secara geografis berada antara $8^{\circ}$ $35^{\prime} 45^{\prime \prime} \mathrm{s} / \mathrm{d} 8^{\circ} 36^{\prime} 15^{\prime \prime}$ lintang selatan dan $116^{\circ} 04^{\prime} 15^{\prime \prime}$ - $116^{\circ} 04^{\prime} 30^{\prime \prime}$ Bujur Timur. 
Kelebihan dari Pantai Tanjung Karang adalah berada di dekat kota Mataram Lombok dan merupakan tempat yang sangat strategis untuk pengunjung menikmati sunset. Pantai Tanjung Karang merupakan kawasan pantai sekaligus menjadi wisata sejarah dan juga wisata religi karena terdapat Makam Loang Baloq. Makam Loang Baloq merupakan makam para penyebar agama islam di pulau lombok pada zaman dulu. Sehingga menjadi daya tarik tersendiri untuk berkunjung di pantai Tanjung Karang.
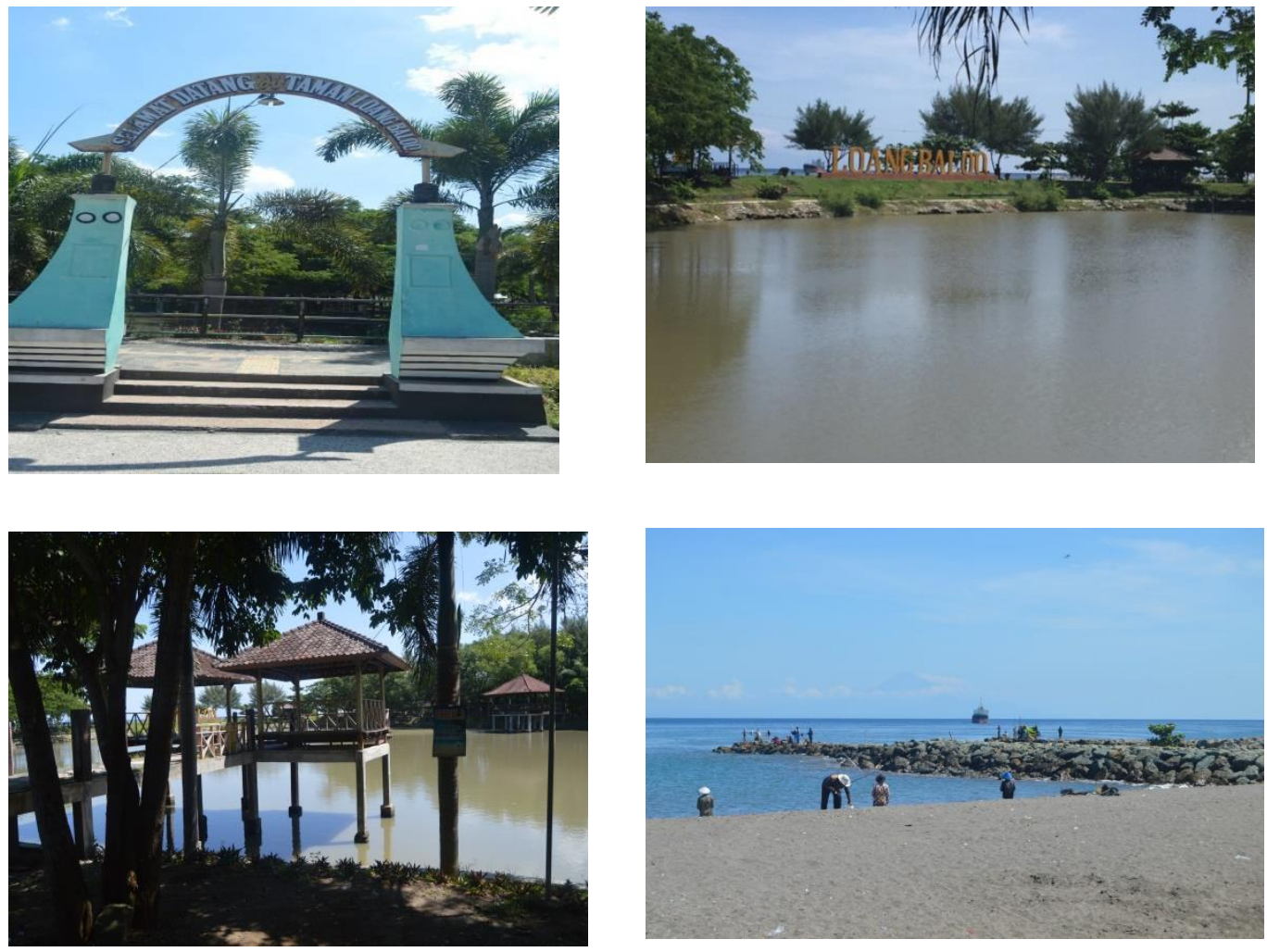

Gambar 1.6 PantaiTanjung Karang dan Makam Loang Baloq Sumber Foto: Dokumen Pribadi

Pantai Tanjung Karang merupakan bagian dari unsur Kawasan Pinggiran Pantai (Waterfronts) karena merupakan kawasan pinggiran pantai sebagai daya tarik wisata alam, letaknya dekat dengan kota Mataram Lombok dan memiliki peluang untuk dikembangkan sebagai daya tarik wisata kota. Selain pantai terdapat juga taman rekrasi Loang Baloq yang memiliki cerita sejarah religi sehingga menjadi daya tarik tersendiri. Dengan demikian Pantai tanjung karang mempunyai peluang untuk meningkatkan perekonomian kota Mataram Lombok dilihat dari jumlah kunjungan wisatawan yang datang ke Pantai Tanjung Karang meningkat tiap tahunnya pada saat liburan, serta berdampak baik bagi masyarakat kota Mataram Lombok karena dengan berkembangnya pariwisata di kota mataram Lombok maka peluang pekerjaan pun terbuka untuk masyarakat setempat.

\section{- Pusat Konvensi dan Pameran (Convention Center and Exhibition)}

Menurut Ruetsche.J.2006 Pusat Konvensi dan Pameran sering dianggap sebagai salah satu bahan pokok pariwisata kota. Di beberapa kota, sampai empat puluh persen dari mereka yang menginap semalam datang untuk jenis wisata bisnis ini. Pusat konvensi dan pameran dianggap sebagai sektor pertumbuhan yang kuat dimana 
pengunjung menghabiskan jumlah rata-rata di atas dan beroperasi hampir sepanjang tahun. Pekerjaan, publisitas, perbaikan citra, dan regenerasi perkotaan adalah keuntungan yang umumnya membenarkan investasi keuangan besar untuk pusat-pusat tersebut. Selain keunggulan ini, penting untuk diingat bahwa bisnis konferensi tidak dapat dipisahkan dari industri pariwisata lainnya terutama karena sebagian besar peserta juga mencari fasilitas perkotaan yang memiliki pariwisata yang menarik untuk dikunjungi.

Kota Mataram Lombok bisa dijadikan tempat Meeting, Incentive, Convention, dan Exhibition, tapi akomodasi berupa hotel di kota Mataram hanya memenuhi untuk Meeting dan Incentive saja. Sementara untuk convention dan exhibition, belum bisa terpenuhi karena standar fasilitas untuk menggelar kegiatan convention and exhibition tidak ada di kota Mataram Lombok. Sehingga unsur Pusat Konvensi dan Pameran perlu diperhatikan karena dengan adanya kegiatan Pusat Konvensi dan Pameran dapat memberikan keuntungan baik berdampak pada peningkatan ekonomi kota Mataram Lombok maupun berdampak pada kelangsungan pariwisata perkotaan di Mataram Lombok karena bisnis convention tidak dapat dipisahkan dari industri pariwisata lainnya.

- Festival dan Acara (Festivals and Events)

Menurut Ruetsche.J.2006 Festival dan Acara (Festivals and Event) telah menjadi sarana yang semakin populer bagi kota-kota untuk meningkatkan pariwisata.Festival dan Acara (Festivals and Events) dapat berukuran atau berskala besar seperti pada acara pameran dunia atau Olimpiade dan juga acara tahunan Festival Musik Rakyat atau Galeri Malam. Kacamata seperti itu penting, namun, dampaknya terhadap industri wisata kota bergantung pada kehadiran, dan jenis dan jumlah pengunjung dari luar yang hadir pada acara tersebut.

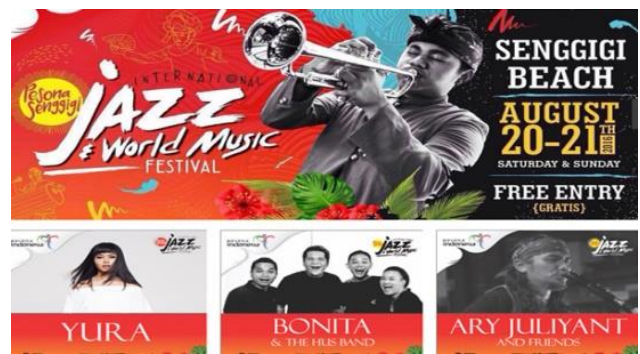

Gambar 1.7 Festival Jazz Di Kota Mataram Lombok

Sumber: wartajazz.com

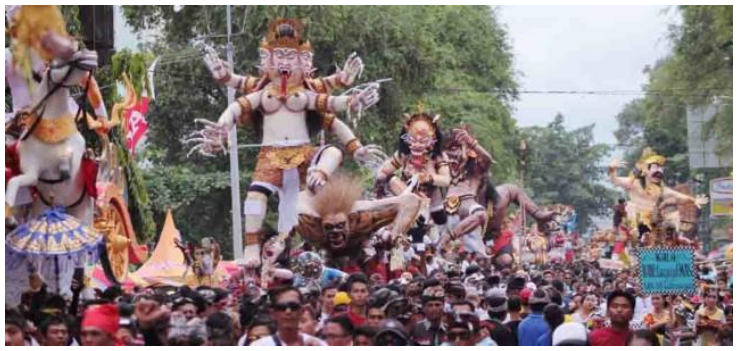

Gambar 1.8 Festival Parade Tahun Baru Caka

Sumber Foto: suarantb.com 
Festival yang diselenggarakan di kota Mataram Lombok merupakan bagian dari unsur festival dan acara (Festivals and Events) antara lain: Parade Tahun Baru Caka, dimana merupakan rangkaian dari Hari Raya Nyepi Umat Hindu. Dikenal sebagai parade Ogoh-Ogoh ini dikuti oleh ratusan Ogoh-Ogoh. Parade Tahun Baru Caka merupakan tradisi budaya yang terus dilestarikan sebagai kekayaan budaya Nusantara. Selain itu ada juga event Mataram Lombok Great Sale dimana even untuk mendongrak angka kunjungan wisatawan pada awal tahun. Terdapat beragam diskon tiket penerbangan, hotel, paket travel, produk kerajinan, dan kuliner. Ada juga festival Jazz Lombok yang merupakan pagelaran terbesar di Kota Mataram. Menampilkan artis nasional dan Internasional dengan musikalitas berkelas internasional. Pertunjukkan ini akan diperkuat oleh tata suara dan tata lampu yang gemerlap sehingga menjadikan event ini menjadi yang termewah sepanjang tahun ini. Festival permainan rakyat dimaksudkan untuk menghadirkan kembali permainan lokal ditengah masyarakat. Perkembangannya permainan berteknologi tinggi, menjadikan permainan rakyat tidak boleh dihilangkan diharapkan festival seperti ini akan mampu mengingatkan dan menghidupkan lagi kecintaan masyarakat akan permainan lokal. Permainan lokal seperti "Begasingan" atau bermain gasing, Selodor dan sejumlah permainan rakyat lainnya akan ditampilkan di ajang ini. Dengan adanya agenda festival \& acara di Mataram Lombok menjadi sarana untuk meningkatkan pariwisata perkotaan serta dapat menarik wisatawan untuk berkunjung.

\section{- Daerah Wisata Perkotaan (Special Visitor Districts)}

Menurut Ruetsche.J.2006 Daerah wisata perkotaan adalah tempat dimana kombinasi atraksi wisata perkotaan seperti budaya, hiburan, atau fasilitas olahraga dikelompok di satu lokasi. Kota ini bukan sekadar strategi untuk menarik wisatawan dan memberikan fasilitas yang lebih baik bagi penduduk setempat, namun juga dapat digunakan untuk memfasilitasi pembaharuan pariwisata perkotaan. Daerah wisata perkotaan memungkinkan pengunjung untuk bergerak dengan mudah dari satu atraksi ke atraksi yang lain, dan jika ini diketahui sebelumnya, dapat mendorong lebih banyak pengunjung untuk datang ke kota karena adanya atraksi yang menarik.

Kota Tua Ampenan Mataram adalah pusat perniagaan pada zaman hindia belanda dan pusat pelabuhan pada saat itu, bahkan Ampenen masih menjadi pusat pelabuhan sebelum pelabuhan dipindah ke Lembar Kabupaten Lombok Barat. Bangunan-bangunan tua di kota tua Ampenan memberikan jejak-jejak peninggalan bangunan zaman kolonial belanda. Kota Tua Ampenan Mataram resmi masuk menjadi salah satu dari 43 kota dalam jaringan Kota Pusaka Indonesia (JKPI). Kota ini dahulunya pernah menjadi salah satu pusat kota di Lombok, kini menjadi sebuah kecamatan di Mataram. Sebagai salah satu kota pusaka, bangunan-bangunan tua berjejer di tepi jalan-jalan di kota tua Ampenen Mataram. Dengan dimasukkanya kota tua Ampenan Mataram sebagai salah satu kota pusaka, pelestarian dan revitalisasi kota ini semakin membuka potensinya sebagai daerah tujuan wisata. 

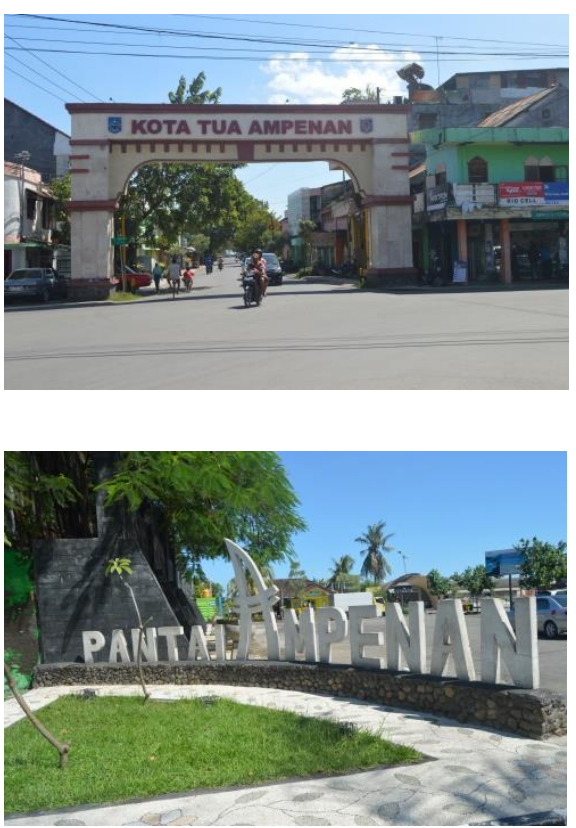
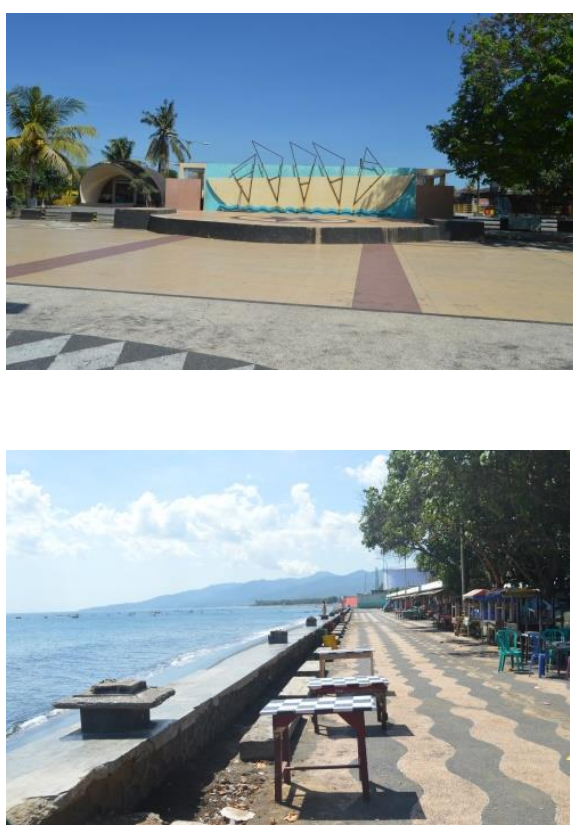

Gambar 1.9 Kota Tua Ampenan Mataram

Sumber Foto: Dokumen Pribadi

Kota Tua Ampenan Mataram merupakan bagian unsur Daerah wisata perkotaan (Special Visitor Districts) karena memiliki kombinasi atraksi sebagai daya tarik wisata kota. Kota tua sendiri memiliki bangunan bersejarah peninggalan era Hindia Belanda, bukan saja bangunan berasitektur belanda, banyak gedung bernuasa tiongkok yang masih berdiri sehingga kota tua dapat dikatakan sebagai daya tarik wisata sejarah. Di kota tua Ampenan juga terdapat pantai Ampenan yang menjadi daya tarik wisata alam bagi wisatawan yang berkunjung. Kota tua ampenan juga terdapat kegiatan festival budaya kota tua ampenan dimana dalam acara festival tersebut terdapat atraksi seni budaya, musik, pameran industri kreatif, festival kopi, aneka macam kuliner, pameran foto kota tua tempo doeloe dan parade lintas ethnic. Dengan demikian kawasan kota tua dapat menarik wisatawan untuk berkunjungan karena memiliki kombinasi atraksi sebagai penunjang wisata kota di Mataram Lombok.

- Warga \& Karyawan yang mendukung pariwisata (Tourism Employees and residents as City Advocates)

Menurut Ruetsche.J.2006 Keramahan tamahan adalah salah satu fitur sosiokultural terpenting dari produk pariwisata. Profesionalisme dan keunggulan pelayanan ditawarkan kepada pengunjung mulai dari awal datang sehingga kembali kedaerah asal. Faktor kunci dalam keputusan pengunjung untuk berkunjung adalah kota tersebut memiliki keramah tamahan sehingga pengunjung akan kembali lagi dan akan selalu diingat akan kota tersebut. Tanggung jawab dalam menerima wisatawan, tidak terletak hanya kepada karyawan pariwisata saja. tetapi Setiap orang yang bekerja dan tinggal di kota wisata yang memiliki kontak langsung dengan pengunjung, dan bisa memasarkan kepada jenis pengunjung yang dibutuhkan untuk membawa lebih banyak uang ke restoran, hotel, museum dan tempat hiburan lainnya. Jika pariwisata perkotaan ingin terus tumbuh dan berkembang maka semua orang, dari sopir taksi ke 
pemilik toko dan penduduk, harus bertindak sebagai agen pariwisata dan memberi pengalaman yang mengesankan bagi pengunjung.

Kota Mataram Lombok merupakan bagian dari unsur warga \& karyawan yang mendukung pariwisata (tourism employees and residents as city advocates) dilihat dari masyarakat kotanya yang sadar akan pariwisata di kota Mataram Lombok. Contohnya hotel-hotel yang terdapat di kota Mataram Lombok sudah sesuai dengan standar nasional maupun internasional baik dari sisi produk, pelayanan, dan fasilitasnya. Memiliki pemandu wisata yang mampu memberikan informasi mengenai pariwisata perkotaan di Mataram Lombok contohnya ditempat-tempat bersejarah dikota Mataram Lombok. Memiliki rental mobil untuk wisatawan bisa menyewa guna berkunjung ke atraksi wisata di Mataram Lombok.Tersedia juga toko-toko souvenir yang berciri khas mataram Lombok dengan pelayanan yang ramah. Memberikan bantuan atau informasi kepada wisatawan yang berkunjung dengan ramah. Sehingga wisatawan punya alasan untuk kembali lagi ke Mataram Lombok dalam melakukan perjalanan wisata kota.

\section{- Fasilitas Ritel \& Katering (Retail and Catering Facilities)}

Menurut Ruetsche.J.2006 meskipun belanja dan restoran dianggap sebagai elemen sekunder pariwisata, ini masih merupakan bagian penting dari ekonomi pariwisata karena pengunjung menghabiskan banyak waktu dan uang untuk berbelanja dan makan. Belanja misalnya, bagi beberapa pengunjung menjadi aktivitas santai di mana mereka berbelanja tanpa tujuan khusus. Bagi pengunjung lain, ini lebih seperti olahraga dimana mereka pergi dari toko yang satu dan ke toko yang lain untuk melihat apakah ada barang yang berbeda yang dijual di tempat tujuan dibandingkan dengan di daerah asal. Kota-kota yang menambahkan toko ritel atau restoran ke pusat kota atau ke fasilitas khusus seperti bandara, stasiun kereta api, atau kasino, mengalami dampak ekonomi positif yang tidak hanya berlaku untuk satu lokasi, namun berdampak juga bagi lokasi di kota lainnya.

Kota mataram lombok termasuk dalam unsur fasilitas ritel \& katering (Retail and Catering Facilities) dilihat dari memiliki restoran yang mempunyai menu khas andalan yaitu "Ayam Taliwang". Ini merupakan makanan wajib bagi pengunjung yang datang mengunjungi kota mataram lombok. Daya tarik dari menu ayam taliwang adalah bentuk penyajiannya ayam utuh dengan menu pendampingnya sambal serta plencing kangkung sehingga dapat mengunggah selera makan pengunjung. Dengan demikian pengunjung dapat menghabiskan uang untuk menikmati makan khas dari kota mataram sehingga perekonomian kota mataram terus berjalan dengan baik Karena dampak fasilitas restoran yang dimiliki. 


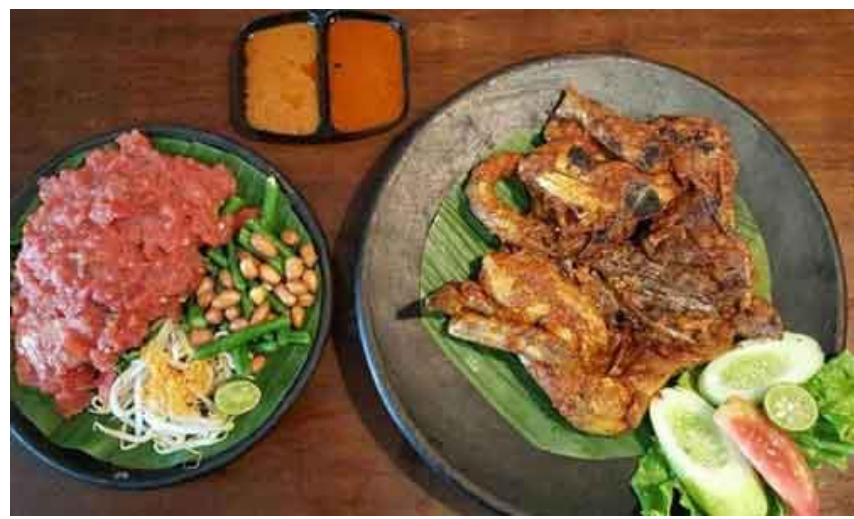

Gambar 1.10 Ayam Taliwang Sumber Foto: malang-post.com

Kota Mataram Lombok juga memiliki kerajinan Emas dan Mutiara Sekarbela, ini merupakan tempat souvenir khas kota Mataram Lombok. Sekarbela merupakan sebuah desa yang berjarak sekitar 4 kilometer dari kota mataram. Desa ini sangat terkenal dengan hasil kerajinan muatiaranya. Mutiara-mutiara yang dijual disekarbela ini merupakan mutiara hasil budidaya air laut dan air tawar.
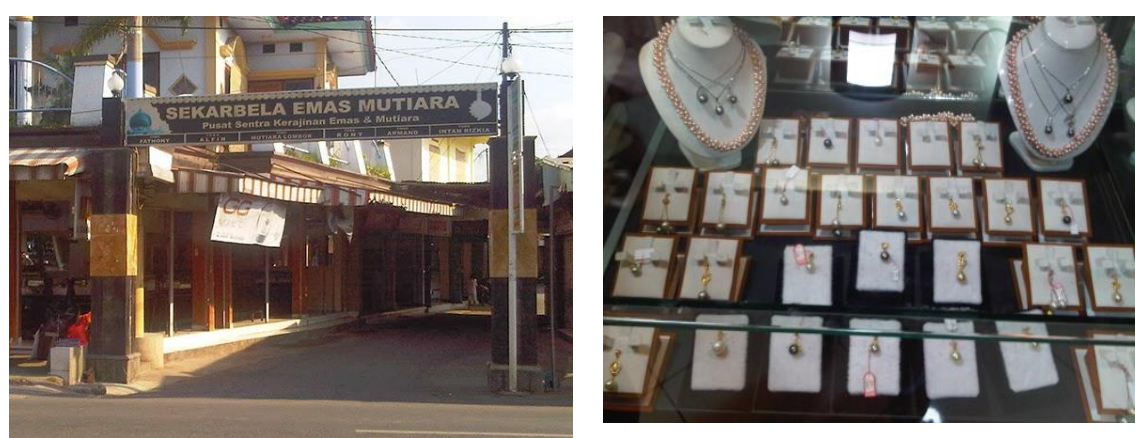

Gambar 1.11 Kerajian Emas dan Mutiara Sekarbela Sumber foto: Kompasiana.com

Kerajian Emas dan Mutiara Sekarbela juga merupakan bagian dari unsur Fasilitas Ritel \& Katering (Retail and Catering Facilities) dimana toko-toko yang menjual kerajinan Emas dan Mutiara terus tumbuh dan berkembang sehingga berdampak baik pada perekonomian pariwisata perkotaan di Mataram Lombok. Mutiara sekarbela merupakan ciri khas dari kota Mataram Lombok sehingga pengunjung yang datang bisa menghabiskan banyak waktu dan berbelanja mutiara sebagai souvenir dari kota mataram Lombok. 


\section{b. StrategiPengembangan Pariwisata Perkotaan Terhadap Tingkat Kunjungan Wisatawan di Mataram Lombok dengan analisis SWOT.}

Tabel 1.3 Matriks SWOTS analisis Faktor Internal dan Eksternal

\begin{tabular}{|c|c|c|}
\hline Faktor Eksternal & 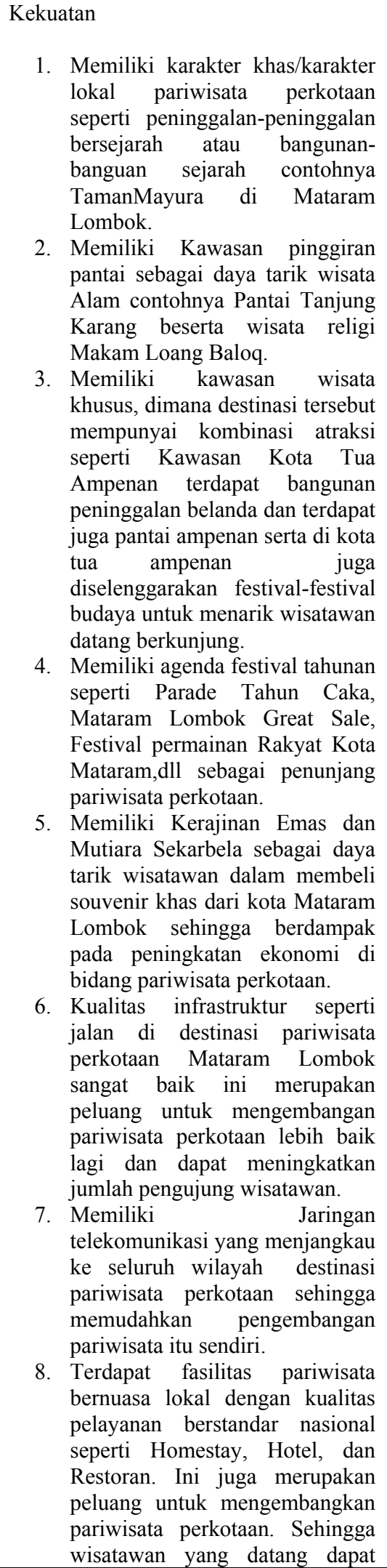 & 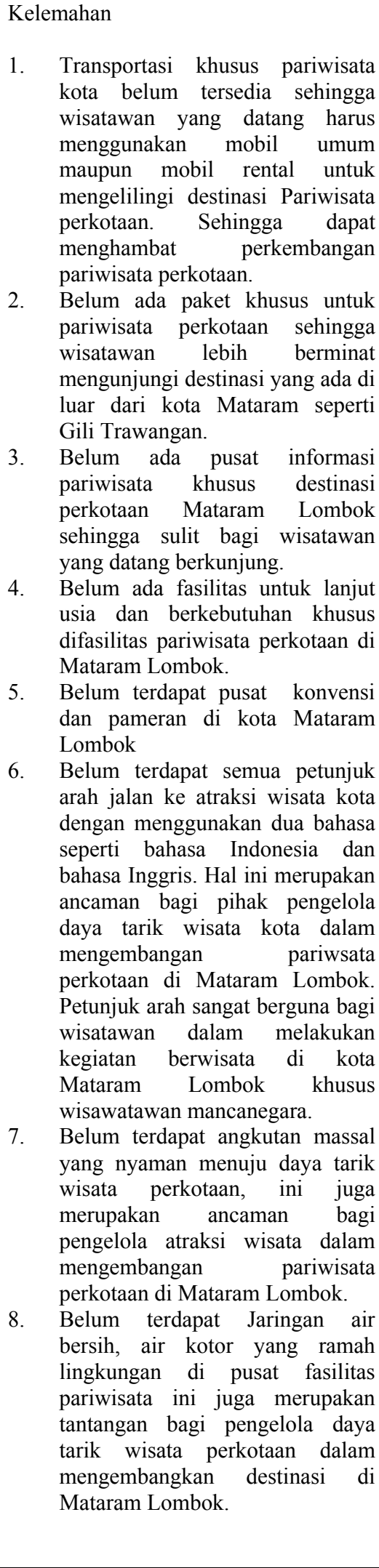 \\
\hline
\end{tabular}




\begin{tabular}{|c|c|c|}
\hline Faktor Internal & 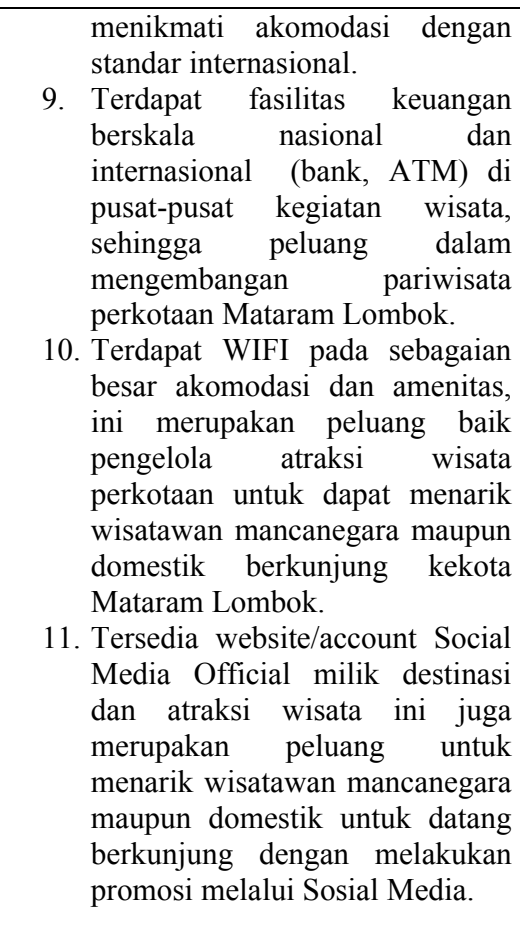 & \\
\hline 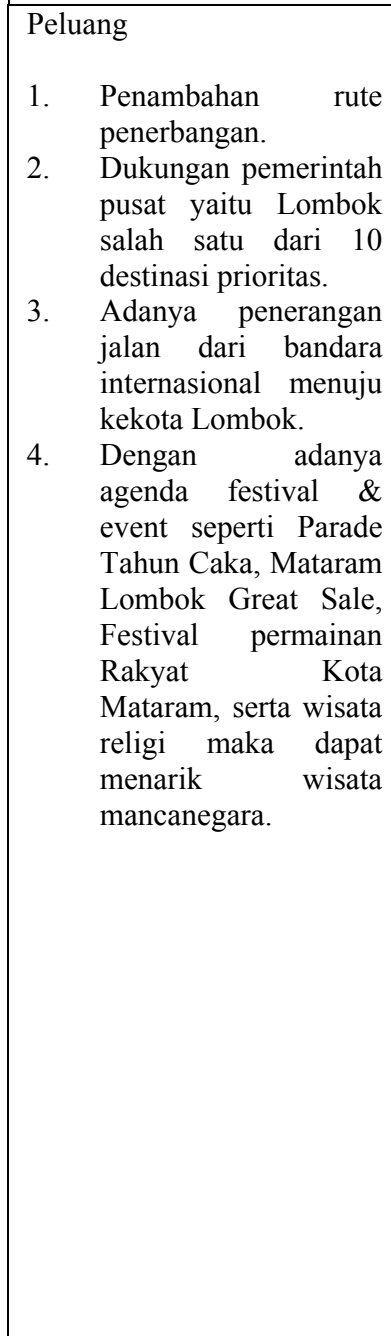 & 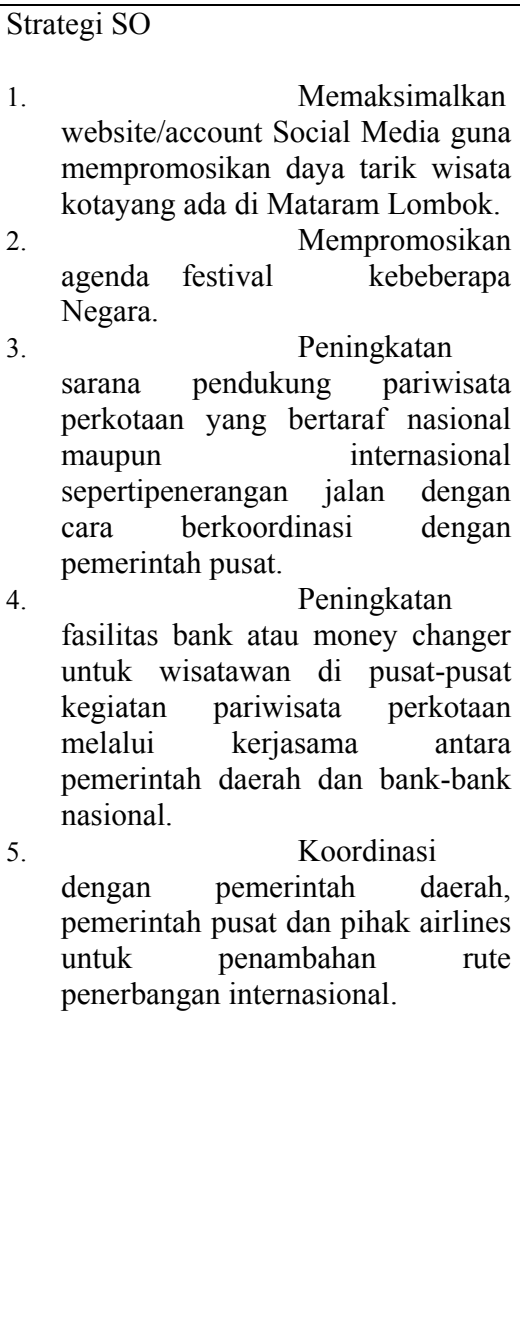 & 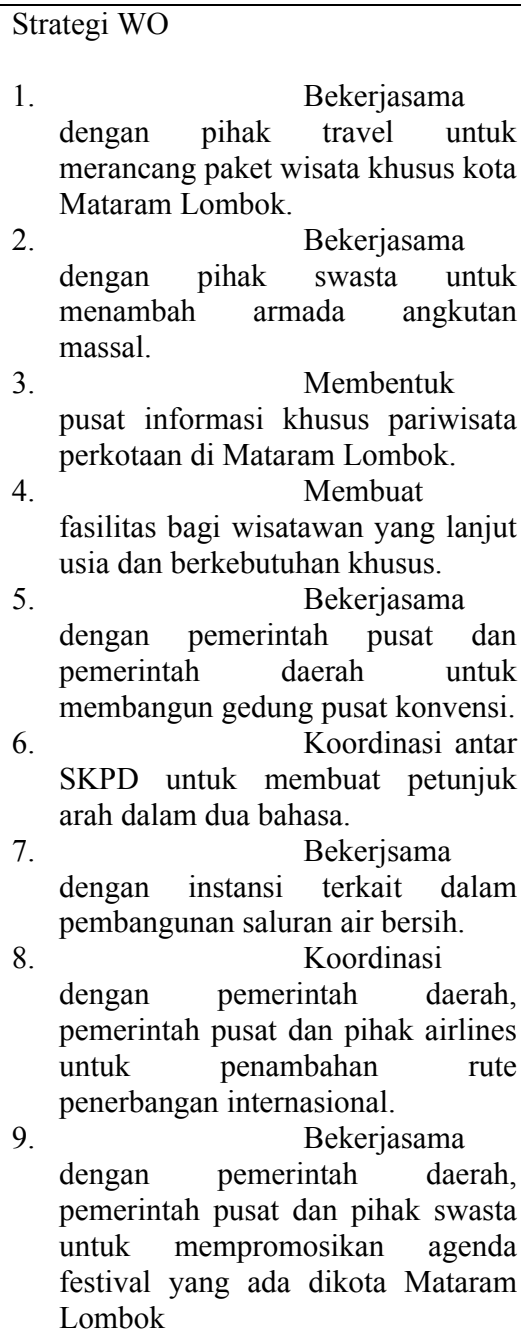 \\
\hline
\end{tabular}




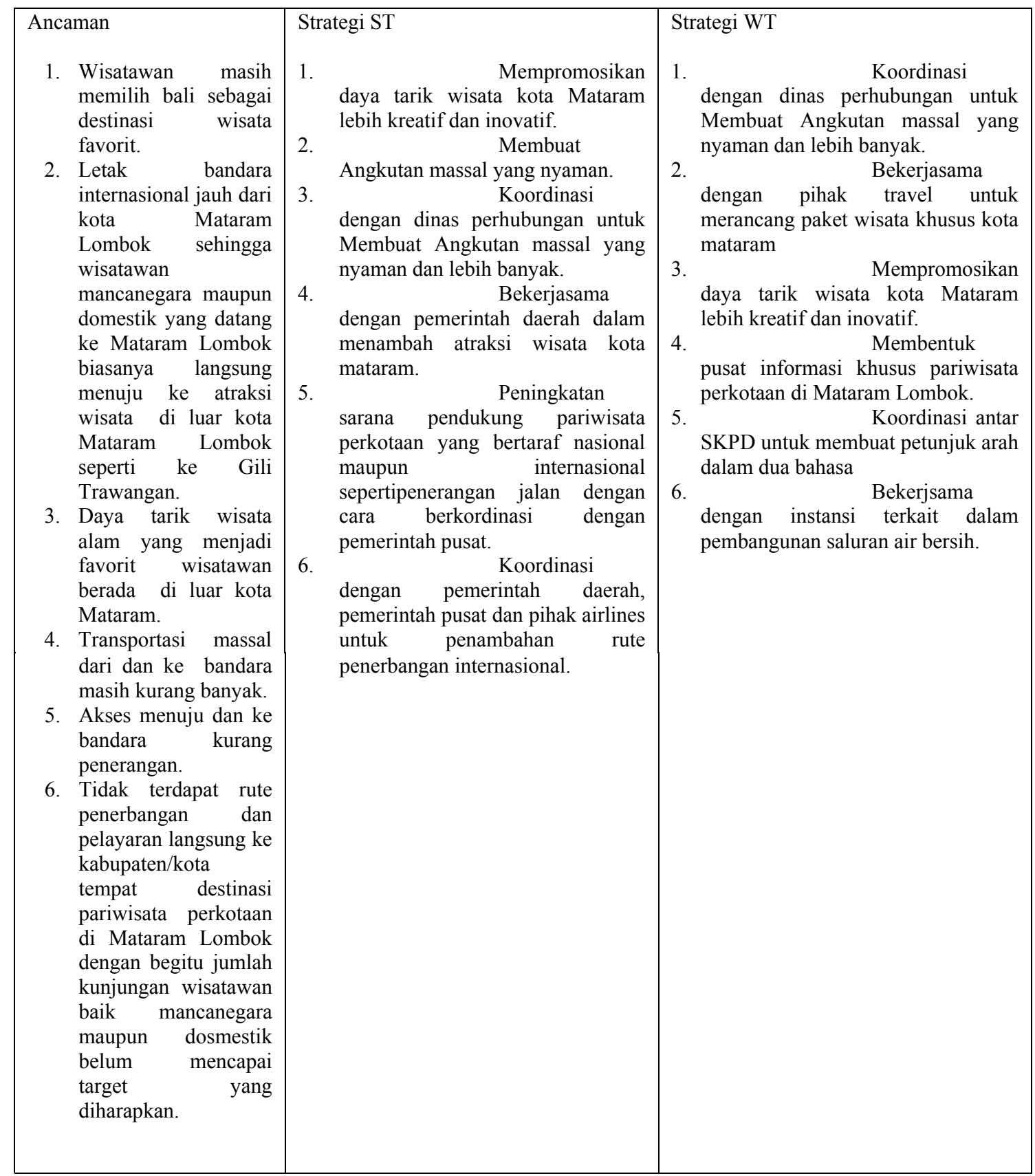

Sumber: Hasil Penelitian 2017 


\section{SIMPULAN}

Dari hasil penelitian didapatkan bahwa elemen pokok daya tarik pariwisata perkotaan yang terdiri dari Kota Bersejarah (Historic District), Kawasan Pinggiran Pantai (Waterfronts), Pusat Konvensi dan Pameran (Convention Center and Exhibitions), Festivals dan Acara (Festivals \& Events), Daerah Wisata Perkotaan (Special Visitor District), Warga \& Karyawan yang mendukung pariwisata (Tourism Employees and Residents as City Advocates), Fasilitas Ritel dan Katering (Retail and Catering Facilities) Hanya ada satu elemen yang belum dipenuhi oleh kota Mataram Lombok sebagai daya tarik wisata kota yaitu Pusat Konvensi dan Pameran (Convention Center and Exhibitions). Kota Mataram Lombok bisa dijadikan tempat Meeting, Incentive, Convention, dan Exhibition, tapi hotel di kota Mataram baru hanya memenuhi Meeting dan Incentive saja. Sementara untuk convention dan exhibition, belum bisa terpenuhi karena standar fasilitas untuk menggelar kegiatan convention and exhibition tidak ada di kota Mataram Lombok. Sehingga unsur Pusat Konvensi dan Pameran perlu diperhatikan karena dengan adanya kegiatan Pusat Konvensi dan Pameran dapat memberikan keuntungan baik berdampak pada peningkatan ekonomi kota Mataram Lombok maupun berdampak pada kelangsungan pariwisata perkotaan di Mataram Lombok karena bisnis convention tidak dapat dipisahkan dari industri pariwisata lainnya.

Pengembangan Pariwisata Perkotaan Terhadap Tingkat Kunjungan Wisatawan di Mataram Lombok dengan analisis SWOT dapat dilihat dari hasil Strategi WO yang terdiri dari bekerjasama dengan pihak travel untuk merancang paket wisata khusus kota mataram, bekerjasama dengan pihak swasta untuk menambah armada angkutan massal, membentuk pusat informasi khusus pariwisata perkotaan di Mataram Lombok, membuat fasilitas bagi wisatawan yang lanjut usia dan berkebutuhan khusus, bekerjasama dengan pemerintah pusat dan pemerintah daerah untuk membangun gedung pusat konvensi, koordinasi antar SKPD untuk membuat petunjuk arah dalam dua bahasa, bekerjasama dengan instansi terkait dalam pembangunan saluran air bersih, Koordinasi dengan pemerintah daerah, pemerintah pusat dan pihak airlines untuk penambahan rute penerbangan internasional, bekerjasama dengan pemerintah daerah, pemerintah pusat dan pihak swasta untuk mempromosikan agenda festival yang ada dikota Mataram Lombok. 


\section{DAFTAR PUSTAKA}

Adriani,Y.2011. Pariwisata Perkotaan: Teori \& Konsep. Tentangpariwisata.blogshot.com/2011/01/pariwisata-perkotaan-teori-dankonsep.html.

Ashworth, G., Page, S.J.2010. Urban Tourism Research: Recent Progress and Current Paradoxes. Journal Homepage: www.elsevier.com/locate/tourman.

Banyaknya kunjungan wisatawan keprovinsi Nusa tenggara Barat 20092013.ntb.bps.go.id

Budi.S.P.2015. Strategi Pengembangan Kawasan Pariwisata Perkotaan Studi Kasus Jakarta.University Research Colloquium.

BPK RI Perwakilan Propinsi Nusa Tenggara Barat.www.mataram.bpk.go.id.

Ghony.M.D \& Almanshur.F, 2012.Metodologi Penelitian Kualitatif. Jogyakarta: ArRuzz Media.

Ismail, H.N \& Baum,T.G. 2006. The Concept of Urban Tourism in developing counties characteristic and experiences of tourism development in Malaka (Malacca) City Malaysia. Anatolia, 17 (2).Pp.1-23.

Jadwal Event dan Pegelaran.2017. DInas Kebudayaan \& Pariwisata Kota Mataram

Mirajanatin, H.P., Sutikno, F.R., Sari, N. 2013. Kajian Potensi Pariwisata Perkotaan di Kota Malang Berdasarkan Stakeholder.Jurnal Tata Kota \& DaerahVol.5 N0.1.

Mataram-Dolan Dolen.https://dolandolen.com/detistination/nusa-tenggarabarat/mataram. Kota mataram merupakan kota sekaligus menjadi ibukota dari provinsi nusa tenggara barat, Indonesia

Peta Kota: Peta Kota Mataram-Lombok. Peta-kota.blogspot.com/2011/05/peta-kotamataram-lombok.html.

Priono, Y. 2012. Identifikasi Produk Wisata Pariwisata Kota (Urban Tourism) Kota Pangkalanbun sebagai Urban Heritage Tourism.Journal Perspektif Arsitektur Vol.07 No. 02.

Ratman.D.R.2016. Pembangunan Destinasi Pariwisata Perioritas 2016-2019. Deputi Bidang Pengembangan Destinasi \& Investasi Pariwisata Kementerian Pariwisata.

Ruetsche Judith.2006.Urban Tourism What Attracts Visitors to cities?.Fyi.uwex.edu.

Salma.2009. Mataram Wisata Sejarah, Budaya, \& Religi

Lombok.Dispar.mataramkota.go.id.

Subinarto.D. 2016.Potensi Besar Pariwisata Perkotaan. www.mediabisnisdaily.com

Sugihartoyo \& Widagdo.W.A. 2010. Strategi Pengembangan WIsata Kota Tua sebagai Salah Satu Upaya Pelestarian Urban Heritage Studi Kasus: Koridor Kali Besar, Jakarta Barat. Jurnal Planesa Vol.1, No.1.

Utama.I.G.B.R. Pengembangan Wisata Kota Sebagai Pariwisata Masa Depan Indonesia.www.academia.edu.

Utami, N. G.M.K. 2016.Optimalisasi Produk Pariwisata Perkotaan Sesuai Tren Pariwisata Bertanggung Jawab (Responsible Tourism) di kota Bandung. Barista, Volume 3, Nomor 1.

Wardhani. A.D. 2012. Evolusi Aktual Aktivitas Urban Tourism di Kota Bandung dan Dampaknya Terhadap Pembentukan Tempat-tempat Rekreasi.Jurnal Pembangunan Wilayah \& Kota. 